sub-units in a virus particle. If it is required to 'enclose' a space around a point by a symmetrical arrangement of small identical units, it can be shown that the ratio of the number of sub-units to the volume enclosed is smallest if icosahedral symmetry is employed. This is very probably the principle involved in the construction of Tipula iridescent virus, which has been shown by Williams and Smith ${ }^{25}$ to have the shape of a regular icosahedron of diameter about $1,300 \mathrm{~A}$. The particle is so large that it is rather like a little erystal, in having plane faces, for example. However, the fact that these faces are related by five-fold axes, which cannot exist in a true space-filling crystal, shows that some features of a point-group structure must be involved.

A number of people have helped to make this work possible. In particular we would like to express our thanks to the following: Drs. Schaffer and Schwerdt for providing us with the virus crystals; Prof. E. T. C. Spooner and Dr. F. Fulton for providing focilities at the London School of Hygiene and Tropical Medicine for storing and handling the crystals; Sir Lawrence Bragg for his interest and for putting at our disposal a rotating-anode tube in the Davy Faraday Laboratory of the Royal Institution, and the members of that laboratory for their generous assistance. This work was supported by a research grant No. $E$-1772 from the National Institute of Allergy and Infectious Diseases, U.S. Public Health Service. We also wish to acknowledge financial assistance by the Agricultural Research Council to one of us (J. T. F.), and a grant by the Wellcome Foundation for the purchase of a precession camera.
1 Schaffer, F. L., and Schwerdt, C. E., Proc. U.S. Nat. Acal. Sci., 41, $1020(1955)$.

${ }^{2}$ Sehwerdt, C. E., and Schaffer, F. L., Virology, 2, 665 (1956),

${ }^{3}$ Steere, R. L., and Schaffer, F. L., Biochim. Biophys. Acta, 28, 241 (1959).

${ }^{4}$ Crick, F. H. C., and Watson, J. D., Nature, 177, 473 (1956).

"Crick, F. H. C., and Watson, J. D., "The Nature of Viruses", Ciba Foundation Symposium (J. and A, Churchill, London, 1957).

' Caspar, D. L. D., Nature, 177, 475 (1956).

${ }^{7}$ Klug, A., Finch, J. T., and Franklin, R. E., Nature, 179, 683 (1957).

"Klug, A., Finch, J. T., and Franklin, R. E., Biochim. Biophys. Acta, 25, 242 (1957).

"Schwerdt, C. E., in "Cellular Biology, Nucleic Acids and Viruses", Special pub. N.Y. Acad. Sci., 5, 157 (1957).

${ }^{10}$ Schaffer, F. L., and Schwerdt, C. E., "Advances in Virus Research", 6, 159 (Academic Press, New York, 1959).

11 Finch, J. T., and Klug, A. (in preparation).

${ }^{12}$ Crowfoot, D., and Schmidt, G. M. J., Nature, 155, 504 (1945).

13 Schwerdt, C. E., Williams, R. C., Stanley, W. M. Schaffer, F. L., and Meclain, M. E., Proc. Soc. Exp. Biol. Med., 88, 310

${ }^{14}$ steere, R. L., J. Biophys. Biochem. Cytol., 3, 45 (1957).

${ }^{15}$ Labaw, L. W., and Wyckoff, R. W. G., Science, 123, $3202(1956)$; Arch. Biochem. Biophys., 67, 225 (1957); Kon. Ned. Akad. Wet.', B, 59, 171 (1956).

${ }^{18}$ Klug, A., and Finch, J. T. (in preparation).

${ }^{17}$ Markham, R., Disc. Farad. Soc., 11, 221 (1951). ${ }^{13}$ Harris, J. I., and Knight, C. A., J. Biol. Chem, 214, $215(1955)$.
Niu, C. I., Shore, V., and Knight, C. A. Virology, 6, $226(1058)$.

${ }^{19}$ LeBouvier, G. L., Schwerdt, C. E., and Schaffer, F. L., Virology, 4, $590(1957)$.

${ }^{20}$ Rustigian, R., Havens, P., and Kalner, M., Proc. Soc. Exp. Biol. Med., 8B, 500 (1954), Selzer, G., and Polson, A., Biochim. Biophys. Acta, 15, 251 (1954).

"1 Polson, A., Selzer, G., and van den Ende, M., Biochim. Biophys. Acta, 24, 600 (1957).

${ }^{22}$ Taylor, A. R., and McCormick, M. J., Yale J. Biol. Med., 28, 589 (1956).

${ }^{23}$ Iranklin, R. E., Klug, A., Finch, J. T., and Holmes, K. C., Disc. Farad. Soc., 25, 197 (1958).

2 "Crick, F. H. C., in "The Biological Replication of Macromolecules", Symp. Soc. Exp. Biol., 12, 138 (1958).

2. Williams, R. C., and Smith, K. M., Biochim. Biophys. Acta, 23,

\title{
OBITUARIES
}

\section{Mr. A. G. M. Michell, F.R.S.}

RARELY in the history of engineering can theory and practice have been so happily blended as in the person of Anthony George Maldon Michell, the inventor of the thrust bearing, who died in Melbourne, Australia, on February 17.

Michell was born in London on June 21, 1870, while his parents were on a visit from Australia, to which country they had emigrated seventeen years earlier. His early schooling was in Victoria, but at the age of fourteen he accompanied his brother, J. H. Michell (later professor of mathematics in the University of Melbourne, one of the most distinguished applied mathematicians of his day), to Cambridge, and attended some University lectures there after leaving school. Returning to Melbourne, he graduated in civil engineering at the University in 1895 .

Michell's early experience, which was in hydraulic engineering, led in 1901 to the invention of the Smith-Michell regenerative centrifugal pump, in which much of the energy of the fluid as it leaves the rotor is used to help drive the pump, thereby increasing its efficiency. Two years later he opened his own office, specializing as a consultant, particularly on hydro-electric schemes; the installation at the Mount Lyell copper mines in Tasmania was the first scheme of this kind in Australia.

At this time the most serious difficulty in the design of water turbines lay in the bearings. No satisfactory way of designing bearings to take an axial thrust along the shaft had been discovered, and they gave continual trouble. Michell made a special study of the theory of film lubrication which Osborne Reynolds had published in 1886, and hit on the novel yet simple idea of using pivoted bearing pads which would automatically tilt and provide the tapered film of lubricant essential in Reynolds's theory. At the same time (1905) in a remarkable paper he extended the theory to the case of the tilting pad. Few major inventions have provided so complete a solution of an apparently insoluble engineering problem : certainly in none can advanced mathematies and engineering practice have been more closely linked.

The thrust bearing was of revolutionary importance not only for water turbines but also for marine propulsion. Shafts could now be designed to transmit twenty or thirty times the horse-power previously attainable, and much larger ships than hitherto became possible. But although it was soon being widely used in Australian installations, the British Admiralty could not be persuaded to adopt it until about 1913 one was accepted by the German firm of Krupp. Thereafter its use rapidly spread in Britain and elsewhere.

In 1911 Michell successfully applied the tilting. pad principle to the construction of journal bearings, and a further most important and ingenious application appeared some years later in his crankless engine, in which reciprocating motion is converted to rotary 
motion, and vice versa, by means of tilting pads against a swash plate. Like the original thrust bearing, these inventions are notable for their simplicity. The crankless engine has never been widely adopted, although it was successful in Australia in various applications.

Among Michell's other inventions were an impulse turbine, a viscometer, the Michell-Seggel floating pad bearing (jointly with his associate, A. J. Seggel) and hydraulic transmission gear. In 1904 he published in the Philosophical Magazine a most original paper on the optimum design of framed structures, the importance of which is only now being recognized by aircraft engineers. He was also the author of "Lubrication" and part-author of "The Mechanics of Fluids"- -both standard works. He wrote as he thought, with precision, clarity and deep mathematical insight. In 1934 he was elected a Fellow of the Royal Society in the year in which he was first proposed, and in 1943 the Institution of Mechanical Engineers bestowed on him its highest honour, the award of the James Watt International Medal.

Michell never married. Always a modest, retiring man, living quietly with his brother, he was rarely before the public eye. Those who knew him intimately speak of his keen sense of humour, his love of French literature and his wide knowledge of the Australian flora and fauna, which he cultivated at his country home in Victoria. With his passing Australia has lost its most distinguished engineer.

\section{A. J. Francis}

\section{Mr. William Hanson, M.B.E.}

IN the recent death, at a comparatively early age, of Mr. William Ralph Hanson, head of the London Forecasting Office, the Meteorological Office has sustained the loss of one of its most devoted servants.

Born in 1904 into a family of teachers, he too spent some years in that profession, having graduated B.Sc. in geography while at Birkbeck College; but in 1937 he entered the Scientific Civil Service as a forecaster, serving at various stations in the south of England. He received his commission in the R.A.F.V.R. shortly before the Second World War but did not go into uniform until 1941. Associated intimately with the organization of meteorological services in the North African and Italian campaigns, he quickly reached the rank of squadron leader. It was during this period that he first showed his unusual skill in negotiation and, in satisfying not only the Royal Air Force, the Navy and the Army, but also the Americans in these theatres of war, he performed outstanding services and was mentioned in dispatches.

After the War he accepted an interesting appointment in New Zealand, and while there had his early experience of the routine broadcasting of 'weather', experience which was later to be of such value at home. In 1951 he was posted to Habbaniya, returning to Britain in 1953 to take over control of the London Forecasting Office, where until his death on May 3 he filled a post requiring not only a detailed knowledge of the working of the Meteorological Office and of other Government departments, but also an appreciation of the needs of those, outside the Service, needing weather information and advice, be they in industry, commerce, law, the Press or radio. Under his immediate direction, the automatic telephone weather service for London was inaugurated, the 'weather men' of the B.B.C. Television were put on the screen and the Meteorological Office Centenary Exhibition prepared and sent around the country. Hanson was perhaps at his happiest when dealing with such publicity and was particularly successful in bridging the gap between the anonymity of the Civil Service and the extrovert activities of Fleet Street and Lime Grove, in which places he was regarded with respect and affection. Although he worked mainly in the background, from time to time he broadcast to farmers on television and on the sound programme "The Countryside".

Early promise at the piano, violin and organ indicated a possible career in the musical profession, but of latter years his main interest, apart from Freemasonry, was undoubtedly the London Forecasting Office and the developing of new ways of presenting weather to the public. He engaged in no research and published no papers, but nevertheless was always experimenting in novel forms of presentation, and he will long be remembered for his eontributions in this field.

He was much devoted to his wife and four children who survive him.

\section{NEWS and VIEWS}

\section{The Queen's Birthday Honours List}

THE following names of scientists and others associated with scientific work appear in the Queen's birthday honours list :

Baronet: Prof. R. Platt, professor of medicine, University of Manchester, and president, Royal College of Physicians.

K.B.E.: Sir David Brunt, emeritus professor of meteorology, University of London, for services in the organization of the International Geophysical Year ; Prof. C. A. Cotton, emeritus professor of geology, Victoria University College, Wellington, New Zealand.

Knights Bachelor: Prof. D. Baird, regius professor of midwifery and gynæcology, University of Aberdeen; L. C. Gamage, chairman and managing director, General Electric Co., Ltd.; Prof. W. V. D. Hodge, Lowndean professor of astronomy and geo- metry, University of Cambridge; Prof. A. J. Lewis, professor of psychiatry, University of London.

C.M.G. : T. S. Leach, chief inspector of fisheries, Ministry of Agriculture, Fisheries and Food; Prof. J. P. Baxter, vice-chancellor, University of New South Wales, and chairman, Australian Atomic Energy Commission; A. J. Haddow, director, East African Virus Research Institute; J. G. M. King, director of agriculture, Uganda; T. A. M. Nash, director, West African Institute for Trypanosomiasis Research ; R. J. M. Swynnerton, director of agriculture, Kenya.

C.B.E. : Prof. W. J. G. Beynon, professor of physics, University College, Aberystwyth, for services in the organization of the International Geophysical Year ; W. E. China, keeper of entomology, British Museum (Natural History); Prof. S. J. Davies, dean, Royal Military College of Science; Prof. W. R. Hawthorne, 